\title{
Human Resource Management - Emotional Intelligence: Communication Effectiveness mediates the Relationship between Stress Management and Job Satisfaction
}

\author{
Hassan Jorfi ${ }^{1}$, Hashim Fauzy Bin Yaccob $^{2}$, Ishak Md Shah ${ }^{3}$ \\ ${ }^{1}$ Universiti Teknologi Malaysia (UTM) \\ haassan_jorfeedyahoo.com \\ ${ }^{2}$ Universiti Teknologi Malaysia (UTM) \\ hfauzy@utm.my \\ ${ }^{3}$ Universiti Teknologi Malaysia (UTM) \\ ishak@utm.my
}

\begin{abstract}
Stress management remains a key topic of concern among managers and employees worldwide. The most significant contribution of this research is the discovery the stress management related to communication effectiveness, and on the other hand, communication effectiveness related to job satisfaction within organizations of Iran. Communication effectiveness is a crucial factor for organization's performance and growth and plays an important role in stress management, and job satisfaction of today's competitive organizations. According to literature on business area and logical arguments we proposed that communication effectiveness can moderators the link between stress management with job satisfaction. The respondents consist of 133 form educational administrations and Agriculture Bank of Iran. The method that used to maintain the stress management, communication effectiveness and job satisfaction is Kendall's coefficient of concordance. Results indicate stress management of emotional intelligence has a positive relationship with communication effectiveness and also communication effectiveness plays a key role in job satisfaction.
\end{abstract}

\section{KEYWORDS}

Emotional Intelligence, Stress Management, Communication Effectiveness, Job Satisfaction.

\section{INTRODUCTION}

In this complex situation organization both public and private sector have to manage change in an effective way. Emotional Intelligence plays a critical role in helping the managers and employees to cope with this dynamic change in the business environment. Dalip Singh mentioned that application of emotional intelligence supports the managers and employees to recognize and understand emotions and using emotional intelligence to manage oneself and his/her relationship with others [4]. The organizations must coach their employees in developing their interpersonal DOI : $10.5121 /$ ijmit.2011.3401 
International Journal of Managing Information Technology (IJMIT) Vol.3, No.4, November 2011

skills and coach them to perform effectively on the job with other employees in the organization [15]. Management of emotional intelligence by the team members will help in developing interpersonal skills of the team members. Organization's to be successful, need to develop employee's emotional intelligence skills to work effectively in the organization. [2]. The most important dimension of Bar-On EQ-i is stress management. The researcher in this paper studied relationship between stress management and communication effectiveness. Stress management refers to a set of programs or techniques intended to help people deal more effectively with stress. Many of these programs are oriented toward job- or workplace-related stress in that burnout is a frequent result of long-term occupational stress. On the other hand, Communication plays a key role in the management of professional organizations and their achievement of development. Communication effectiveness has long been held to be a success factor for managers. Effective communication can add value to organizations [8]. Fisher states that communication effectiveness is a vital factor in the workplace, in relationships, and in everyday life [6]. Communication effectiveness in organizations can unite the managers, workers, decision making, and improve teamwork [8]. Stress management transformed progressively from a mere notion into a dominant theory in many research areas within which its effects on human behavior were analyzed. Recently, Stress management received much interest in effective communication. Results of these studies indicated that Stress management played a pivotal role in human communication. The need to establish the relationship between Stress management and effective communication was recognized. This manuscript describes Stress management of managers and employees have a direct role to improve communication effectiveness. However, the empirical evidence is scant [1], and no study has examined the interaction effect of managers' stress management and employees' stress management on communication effectiveness. As such, the goals of this study are to examine the impact of manager and employees' stress management and communication effectiveness on job satisfaction.

\subsection{STRESS MANAGEMENT}

One of Bar-On EQ-i component is the stress management component. It is defined by two subcomponents in specific: "stress tolerance (ability to withstand adverse events through positive, active coping) and impulse control (ability to resist or delay an impulse, drive, or temptation to act)" ([14], [5]). Research points out that emotionally intelligent individuals manage more productively because they "accurately perceive and appraise their emotional states, know how and when to express their feelings, and can effectively regulate their mood states" ([14], [5]). Managing office is not an easy occupation ([16], [7], [10). One of the difficulties in working in the public education system is dealing with individuals that are undergoing various, simultaneous neurophysiologic, body, and emotional changes. Managing is considered and labeled to be a stressful occupation. Managers are expected to regulate their mood with caution so as not to damage the interpersonal relationships they develop with others in the academic setting [10]. A foundation of stress on the job implicates the inadequate relationships between group members, including subordinates, colleagues, and employees. This is marked by little trust, little supportive, and little interest in listening and trying to deal with problems that comfort organizational members. Data most frequently reported source of work-related stress ([5], [11]).

\subsection{COMMUNiCATION EFFECTIVENESS}

Communication effectiveness is an essential part of human interaction. The benefits of effective communication are many and obvious as they enhance all aspects of our personal and 
International Journal of Managing Information Technology (IJMIT) Vol.3, No.4, November 2011

professional lives. Ineffective or misunderstood communications in our personal lives may give rise to problems or embarrassment but in our professional lives the results of misunderstandings may have much more serious results. According to Campbell communicative effectiveness is deliberate behavior aimed at augmenting the result of an interpersonal meeting [3]. Similarly, the expression "communication effectiveness" is often replaced by, "effective communication" ([17], [18], [20]). A high level of communication effectiveness leads to a high degree of similarities of understandings between the sender and the receiver [19]. In this case, the communication effectiveness of the group managers has positive correlation with maximizing understanding or minimizing misunderstanding of group workers with job satisfaction.

\subsection{JOB SATISFACTION}

Job satisfaction is vital in the day to day life, which is far past the studies and literature related to research. Job satisfaction can be defined as an encouraging emotional condition as a result from the features and characteristics of a work environment ([9], [13]). Organizations produce noteworthy effects on their employees and a number of those effects are indicated in how people feel about their jobs [12].

\subsection{RELATIONSHIP BETWEEN STRESS MANAGEMENT AND COMMUNICATION EFFECTIVENESS}

One of Bar-On EQ-i component is the stress management component. Stress management has a high relationship with communication effectiveness. Stress management is defined by two subcomponents: "stress tolerance (ability to withstand adverse events through positive) and impulse control (ability to resist or delay an impulse, drive, or temptation to act)" ([14], [5]). Research points out that emotionally intelligence people handle more effectively because they "accurately perceive and appraise their emotional states, know how and when to express their feelings, and can effectively regulate their mood states" ([14], [5]). One of the difficulties in working in the public education system is communicating with individuals and employees that are undergoing diverse, simultaneous neuropsychological, body, and emotional changes and this work is considered to be a stressful occupation. Managers are expected to control their mood with caution so as not to damage the interpersonal relationships they improve with others in the educational environment [10]. Infrastructure of stress on the job shows the insufficient communication between group individuals, including managers and employees. It is marked by little belief, little supportive, and little desire in listening to and trying to communicate with troubles that confront organizational individuals. Information recommend that negative communication with employees, workers, clients, colleagues, and managers are the most often informed source of work- related stress ([5], [11]). In summary in current paper, communication effectiveness view of stress management and job satisfaction. The view holds that stress management and job satisfaction are outcomes of the communicative process. It follows that to improve manager effectiveness requires a significant emphasis on communication effectiveness since according to this view; it is through communication effectiveness that stress management and job satisfaction occur. Figure 1 show his relationship. 
International Journal of Managing Information Technology (IJMIT) Vol.3, No.4, November 2011

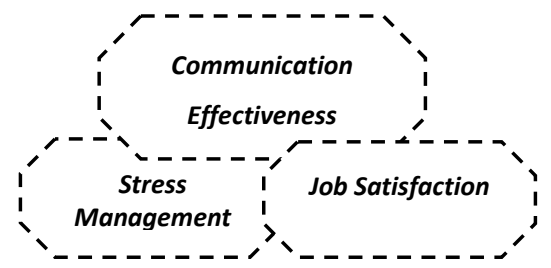

Figure 1 Communication effectiveness View of Stress Management and Job Satisfaction

\section{GOALS AND METHODS}

The goal of the research was to determine the impact of stress management through communication effectiveness on job satisfaction. The research was based on a questionnaire study, which is a quite common form of investigation in this behavior and business field and also provide opportunities for determining whether stress management and communications effectiveness have an impact on job satisfaction. The respondents for the research were selected from the Agriculture Bank and Educational Administrations of Iran. The group comprised (111) persons, out of which (652) respondents completed the questionnaire.

\section{RESEARCH MODEL}

The model for this paper is composed of three key constructs (see Figure2) including stress management, communications effectiveness, and job satisfaction. Based upon the studies and researches, it can be concluded that communication effectiveness affected by many factors. To name a few factors, relationship with motivation, job satisfaction, leadership, emotional intelligence, organizational culture can influence communication effectiveness. For this study, we have focused on emotional intelligence due to some reasons that we have mentioned previously. By reviewing much literature, it was found that emotional intelligence brought about a positive effect on communication effectiveness. Based on the existing literature-as stated there is a positive relationship between stress management with communication effectiveness serving as a mediator of this relationship. Also, communication effectiveness has a positive relationship with job satisfaction. Thus, we can propose that communication effectiveness mediators the link between stress management and job satisfaction. Good communication is factor that has been found to affect job satisfaction [7].

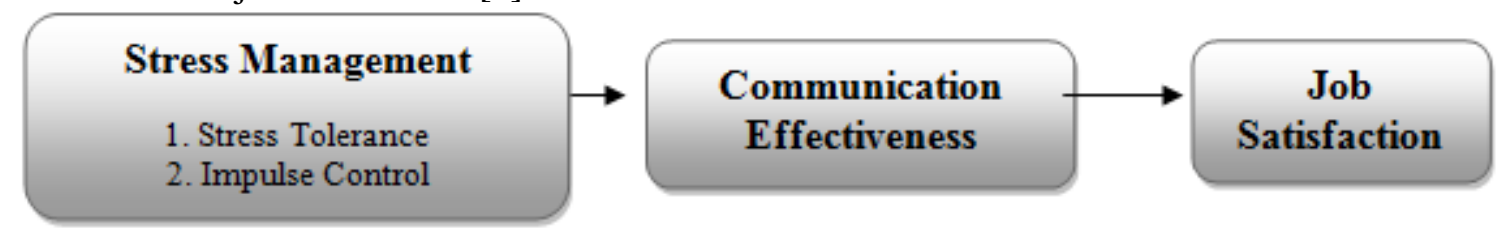

Figure 2 the research model

From the model, the following hypothesis is derived:

- H1: Stress management will have a significant relationship with communications effectiveness.

- H1a: Stress tolerance will have a significant relationship with communications effectiveness.

- H1b: Impulse control will have a significant relationship with communications effectiveness. 
International Journal of Managing Information Technology (IJMIT) Vol.3, No.4, November 2011

- H2: Communication effectiveness will have a significant relationship with job satisfaction.

\section{OUTCOMES AND DISCUSSION}

Stress management is independent variables in this research, communications effectiveness is a mediator variable and job satisfaction in the Agriculture Bank and Educational Administrations of Iran is considered as the dependent variable. The present research is an applicable one with interrelationship. The researcher tries to investigate a connection between variables. The purpose of this applied study and correlation in this research is the assessment of this connection between variables and making on these predictions the researcher looks for a probable relation between Stress management, communications effectiveness, and job satisfaction in Agriculture Bank and Educational Administrations of Iran. Statically group consists of 625 subjects sample volume of about 133 people. Libraries have been used to collect data; sources like: books, journals, magazines, newspapers, scientific reports, organizations archives, field studies and questionnaire by making use of evaluated specter of Likerts' spectrum. For hypothesis test first the average of questions selected to each variables were specified then the software package (SPSS, Ver16) analyzed the connections between both groups of variables. The validity of the questionnaire was evaluated by Cronbach' alpha is formula for measuring the amount of which was $79 \%$ which is acceptable. The consistency of the questionnaire was announced by seven authorities at the average at $89 \%$. Kendall's coefficient of concordance was used to analyze and explain the present research. Based on analyzed via Kendall's coefficient of concordance by the use of (SPSS, Ver16) was performed the results given below were obtained:

H1: Kendal's coefficient between independent variable (stress management) and mediator variable (communication effectiveness) is equal to $70 \%$ and there is significantly positive correlation between two variables considering the fact that a rate of 0.999 is significant.

H1a: there is a significant relationship between the stress tolerance of stress management and communication effectiveness. The correlation coefficient is 0.68 out a significant level of 0.999 , thus, the first hypothesis has been validated.

H1b: there is a significant relationship between impulse control of stress management and communication effectiveness. The correlation coefficient is 0.65 , thus, the second hypothesis has been validated.

H2: Kendal's coefficient between mediator variable (communication effectiveness) and dependent variable (job satisfaction) main hypothesis is equal to $77 \%$ and there is significant positive correlation between the two variables considering the fact that a rate of 0.999 is significant.

\section{CONCLUSION}

Over results have shown there is a significant and positive relationship between independent variable stress management (i.e. stress tolerance and impulse control), and communication effectiveness with dependent variable (job satisfaction) in Agriculture Bank and Educational Administrations of Iran. From the results of the study, we can conclude that the Agriculture Bank and Educational Administrations of Iran should pay much attention to stress management, and 
International Journal of Managing Information Technology (IJMIT) Vol.3, No.4, November 2011

communications effectiveness as they could lead to maintain job satisfaction. We encourage future research to replicate our findings in wider samples in organizations of Iran. It is important to note that prior researches have ignored the link between stress management, communication effectiveness and job satisfaction that the current study was developed with the intention of filling the research gap.

\section{ACKNOWLEDGMENT}

The authors would like to thank University Technology Malaysia (UTM) for its invaluable help in developing and setting up the social tag infrastructure, and in post-processing the raw data. The authors are grateful for the organizations and support they received from Agriculture Bank and Educational Administrations of Iran.

\section{REFERENCES}

[1] A. L., Day, \& S. A. Carroll, (2004)."Using an ability-based measure of emotional intelligence to predict individual performance, group performance, and group citizenship behaviors", Personality and Individual Differences, vol. 36(6), pp. 1443-1458.

[2] B., Wall. (2008). "Working Relationships Using Emotional Intelligence to Enhance your Effectiveness with Other" (1st Ed.), USA: Davies Black Publishing.

[3] D. G. Campbell, (1989). "An empirical comparison of three theories of decent ring", Dissertation Abstracts International, vol. 50 (12), 3792-4320, (UMI No. 9012890).

[4] D., Singh. (2001). "Emotional Intelligence at work" (1st Ed.). New Delhi: Response Books.

[5] G., Matthews, M., Zeinder, \& R.D Roberts, (2002). "Emotional Intelligence: Science and myth", Cambridge, MA: A Bradford Book.

[6] H. Fisher, (1999). "The first sex: The natural talents of women and how they are changing the world", New York: Ballantine Books.

[7] H.K., Wong, \& R.T. Wong, (1998). "The first days of school: how to be an affective teacher", Mountain View, CA: Harry K. Wong Publications, Inc.

[8] H. Thamhain, (1992). "Engineering management: Managing effectively in technology-based organizations", New York: John Wiley \& Sons.

[9] J. Arches, "Social structure, burnout, and job satisfaction". Social Work, 36, 193-272, 1991.

[10] M.C., Wang, G.D., Haertel, \& H.J. Walberg, (1994). "Educational resilience in inner cities". In Margaret C. Wang, \& Edmund W. Gordon (Eds.), Educational Resilience in Inner-City America Challenges and Prospects. Hillsdale, NJ: Lawrence Earlbaum.

[11] M.L., Knapp, \& G.R. Miller, (1994). "Handbook of interpersonal communication", (2nd Ed.), Thousand Oaks, California: Sage Publications, Inc.

[12] P.E. Spector, "Job Satisfaction”, Sage, Thousand Oaks, CA. 1997. 
International Journal of Managing Information Technology (IJMIT) Vol.3, No.4, November 2011

[13] P.L. Dressel, "Policy sources of worker dissatisfaction: The case of human services in aging". Social Service Review, 56, 406 - 423, 1982.

[14] R., Bar-On, (1997). “The Emotional Intelligence Inventory (EQ-i)”, Toronto: Multi-Health systems.

[15] R., Bar-On., J.G. Maree., Maurice, \& J. Elias, (2007). "Educating People to Be Emotionally Intelligent", (1st Ed.). United Kingdom: Greenwood Publishing Group.

[16] T., Wubbles, J., Levy, \& M. Brekelmans, (1997). "Paying attention to relationships", Educational Readership, 54 (7), 82-86.

[17] W.B. Gudykunst, (1993). "Toward a theory of effective interpersonal and intergroup communication: An anxiety/uncertainty management perspective", In R. L. Wiseman, \& J. Koester (Eds.), Intercultural communication competence. Newbury Park: CA: Sage, 1993, pp. 33-71.

[18] W.B. Gudykunst, "Anxiety/uncertainty management (AUM) theory: Current status", In R. L. Wiseman (Ed.), Intercultural communication theory Thousand Oaks, CA: Sage, 1995, pp. 8-58.

[19] W.B. Gudykunst, "An anxiety/uncertainty management (AUM) theory of effective communication: Making the mesh of the net finer", In W. B. Gudykunst (Ed.), Theorizing about intercultural communication, Thousand Oaks, CA: Sage, 2005, pp. 281- 322.

[20] W.B. Gudykunst, "An anxiety/uncertainty management (AUM) theory of effective Communication: Making the mesh of the net finer", In W. B. Gudykunst (Ed.), Theorizing about intercultural communication, Thousand Oaks, CA: Sage, 2005a, pp. 281-322.

\section{Authors}

Hassan Jorfi is a PhD student in management at Universiti Teknologi Malaysia (UTM). His research interests are in the area of emotional intelligence, communication effectiveness, job satisfaction, and motivation. He has published over 60 papers in refereed journals and conference proceedings. Hassan Jorfi has over 10 years of experience working in educational administration and held positions as a manager in thinking room of educational administration. Additionally, he has over 7 years of University teaching experience.

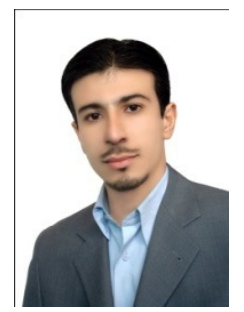

Hashim Fauzy bin Yaccob is Senior Lecturer at Universiti Teknologi Malaysia, Malaysia. He is a Head Department of Human Resource Development. He received his Bachelor (social science and humanities) from National University of Malaysia, Master science in development communication from UPM, and PhD in Human Communication from University Putra Malaysia (UPM). He has published several articles in international journal and conferences of communication, human communication, etc. his teaching experience begins from 1992-present. His areas of specialization are development communication (organizational/managerial communication). He is member of international communication association from 1994 until present.

Ishak Mad Shah is a Senior Lecturer in the Department of Human Resource Development. He received his B.A Hons in (Psychology) from (UKM), M.A. in (Psychology) from (UKM), and PhD in (Educational Psychology) from (UTM). His research interests are in the areas of psychology, and educational psychology, emotional intelligence, and etc. 